\title{
ZnO Nanowire Field Effect Transistor for Biosensing: A Review
}

\author{
N.M.J. Ditshego \\ Electrical, Computer and Telecommunications Engineering Department, CET, Botswana \\ International University of Science and Technology (BIUST), Private bag 16, Palapye, Botswana \\ Email: ditshegon@biust.ac.bw
}

Keywords: zinc oxide ( $\mathrm{ZnO})$, semiconductor device, nanosensor, nanowire field effect transistor (NWFET), biosensors, growth techniques.

\begin{abstract}
The last 19 years have seen intense research made on zinc oxide $(\mathrm{ZnO})$ material mainly due to the ability of converting the natural n-type material into p-type. For a long time, the p-type state was impossible to attain and maintain. The review focuses on ways of improving the doped $\mathrm{ZnO}$ material which acts as a channel for nanowire field effect transistor (NWFET) and biosensor. The biosensor has specific binding which is called functionalisation achieved by attaching a variety of compounds on the designated sensing area. Reference electrodes and buffers are used as controllers. Top-down fabrication processes are preferred over bottom-up because they pave way for mass production. Different growth techniques are reviewed and discussed. Strengths and weaknesses of the FET and sensor are also reviewed.
\end{abstract}

\section{Introduction}

Zinc Oxide $(\mathrm{ZnO})$ material has been known as a semiconductor for over seventy (70) years, with some of the first literature being reported as early as in 1944 [1]. It was never put to use like other semiconductors ( $\mathrm{GaN}, \mathrm{Si}$ ) because it is difficult to dope. The past nineteen (19) years have seen a revival on the research and use of material because of new and emerging ways of doping it. The material is naturally n-type [1]-[4] and by controlling the conditions of growth, the donor concentration can be controlled. The growth conditions include: temperature, diethyl zinc (DEZ) reactant, $\mathrm{O}_{2}$ or $\mathrm{H}_{2} \mathrm{O}$ reactant and pressure. P-type material [1]-[4] is difficult to grow and tends to slowly revert back to n-type. Researchers [5]-[14] that managed to deposit the p-type material have shown that it converts back to n-type within a few days. Maximum time period shown on p-type $\mathrm{ZnO}$ was a few months [5]-[14].

$\mathrm{ZnO}$ is a wide band gap semiconductor $[\mathrm{Eg}(0 \mathrm{~K})=(3.441 \pm 0.003) \mathrm{eV} ; \mathrm{Eg}(300 \mathrm{~K})=(3.365 \pm$ $0.005) \mathrm{eV}]$. It belongs to the group of $\mathrm{II}^{\mathrm{b}}-\mathrm{VI}$ compound semiconductors which crystalizes exclusively in the hexagonal wurtzite type structure. The lattice parameters of the wurtzite crystal structure are $a=3.24 \AA$ and $c=5.21 \AA$. Related to similar II ${ }^{\mathrm{b}}$-VI (e.g CbS, CbSe, ZnSe, ZnS) or III - V (e.g AlSb, Bas, GaN, InSb) semiconductors, it has comparatively strong polar binding and comparatively large exciton binding energy of $(59.5 \pm 0.5) \mathrm{meV}$. Its density is $5.6 \mathrm{gcm}^{-3}$, a value which corresponds to $4.2 \times 10^{22} \mathrm{ZnO}$ molecules per $\mathrm{cm}^{-3}$ [1], [2].

$\mathrm{ZnO}$ has practical advantages that make it an attractive semiconductor from an industrial point of view. It has low costs, abundant, non-toxic, transparent, large excitonic binding energy of $60 \mathrm{meV}$, soluble, compatible with intercellular material, and wide and direct band gap of $3.37 \mathrm{eV}$ making it highly sensitive. It is well known that semiconductors have a small band gap which allows switching between conduction and off-states. The larger the band gap, the better is the semiconductor able to switch states and to insulate leakage currents. Band gap affects sensitivity because a device that possesses a wider band gap allows for higher currents to travel but also preventing leakage currents which results in more sensitive and accurate readings. With low-temperature fabrication processes, high-quality devices can be fabricated using conventional processing technology, thereby making it suitable for low cost mass-production. It has potential applications in opto-electronics, transparent electronics, and spintronics. $\mathrm{ZnO}$ and its alloys has versatile electrical and optical properties for applications in thin film or nanowire transistors, light emitters, biosensors and solar cells. The 
nanowire biosensor has a high surface-to-volume ratio, enabling real time and label-free detection [1]-[4], [15]-[17].

Currently, the main commercial application for $\mathrm{ZnO}$ (and/or IGZO) material is in displays, with companies like Sharp and Samsung putting IGZO into mobile phone displays [18]-[20]. IGZO displays out-perform other semiconductor displays such as amorphous silicon and organic semiconductors by providing improved resolution and reduced power consumption. This is possible because IGZO has a x20 to x50 times higher mobility than amorphous silicon and polymers, which allows for device scaling without affecting performance [18]-[20]. Higher mobility values can also be achieved with amorphous silicon technology, but it needs to be laser annealed which is expensive.

\section{Growth Techniques of $\mathrm{ZnO}$}

$\mathrm{ZnO}$ films can be grown using three methods: gas transport (vapour-phase deposition), hydrothermal synthesis, and/or melt process. Melt growth techniques are a problem due to high vapour pressure of $\mathrm{ZnO}$. Growth using gas transport is difficult to control for large film layers and is normally used for bottom-up $\mathrm{ZnO}$ nanostructures. Hydrothermal synthesis is therefore preferred as a method of growth. Thin films can be produced through: chemical vapour deposition, metalorganic vapour phase epitaxy, electrodeposition, pulsed laser deposition, sputtering, sol-gel synthesis, atomic layer deposition, spray pyrolysis, etc. All the mentioned techniques fall under hydrothermal synthesis and one of the preferred methods is atomic layer deposition (ALD). The ALD process is capable of producing highly conformal and quality films [21]. The process is cyclic and is based on the number of reactants. Fig. 1 shows that the ALD process for $\mathrm{ZnO}$ films is cyclic and depends on two reactants: metallisation and oxidation.

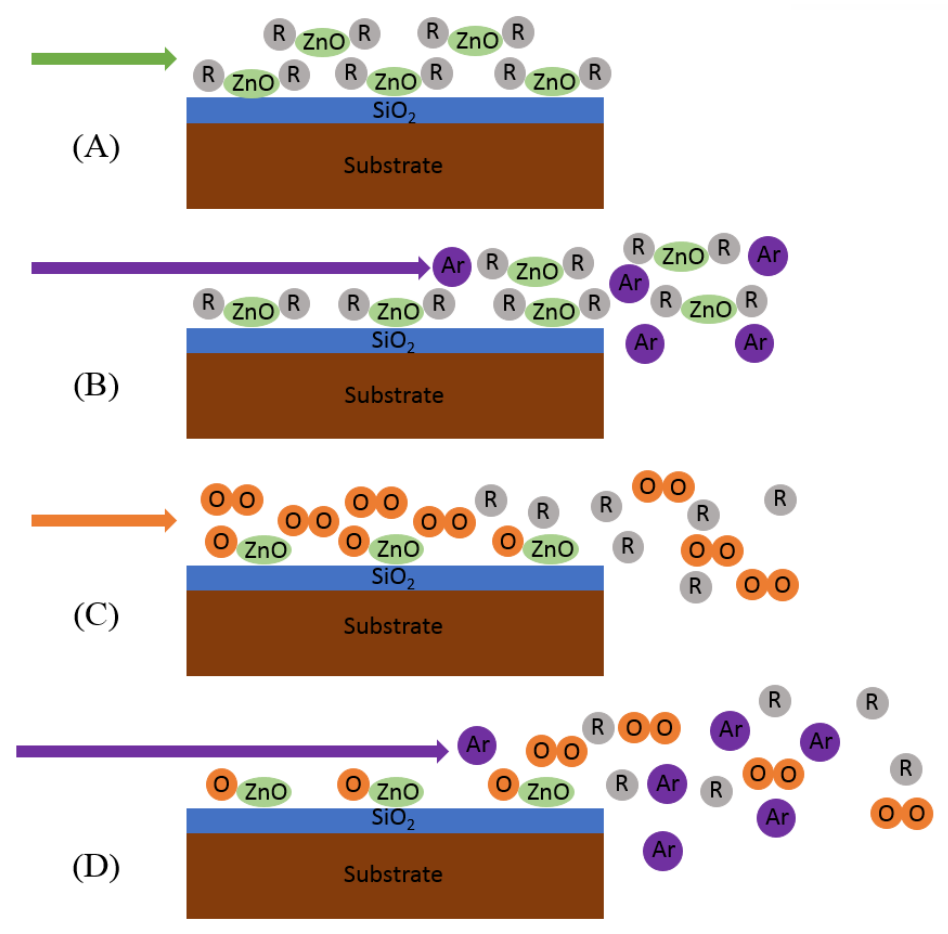

Fig. 1 Schematic diagram illustrating a single cycle of $\mathrm{ZnO}$ deposition using the ALD tool [42]

Metallisation uses diethyl zinc (DEZ) as the zinc ( $\mathrm{Zn})$ metal precursor. Purge and pump steps are used to separate the execution of the reactants and to remove by-products. Before deposition: the wafer (substrate) is pre-heated at a temperature that will be used for deposition and it is also cleaned with $\mathrm{O}_{2}$ plasma so as to remove any polymer layer. During the metallisation step, the DEZ ( $\mathrm{Zn}$ $\left.\left(\mathrm{C}_{2} \mathrm{H}_{5}\right)_{2}\right)$ is absorbed onto the surface of the wafer and the residual $\mathrm{Zn}\left(\mathrm{C}_{2} \mathrm{H}_{5}\right)_{2}$ is removed from chamber. ' $\mathrm{R}$ ' in Fig. represents $\mathrm{C}_{2} \mathrm{H}_{5}$. Then on another step, water or $\mathrm{O}_{2}$ is delivered to react with the absorbed DEZ [22]-[24]. These steps are executed separately and to ensure this, purge steps are introduced in between the steps. 
When water is used instead of $\mathrm{O}_{2}$ for oxidation, the process is called thermal ALD. This process tends to produce films similar to chemical vapour deposition (CVD) techniques [24], [43], [44]. When $\mathrm{O}_{2}$ is used instead of water, then the process needs plasma energy. Remote plasma atomic layer deposition (RPALD) is a fairly new process which is why it is still not in used. It is better than the other deposition techniques as it tends to produce films close to epitaxial layers. The layers are crystalline but tend to be non-uniform to the underlining layer which is why they are not called epitaxial layers. It is a process with great potential for depositing highly conformal and quality films. The process is better than thermal ALD in terms of conformity and quality, but both processes do not generally produce epitaxial layers due to non-uniformity to the underlining substrate. The plasma assisted ALD method has the following advantages: reduction of $\mathrm{OH}$ impurity, allows more freedom in processing conditions and provides wider range of material properties. The $\mathrm{OH}$ impurity is not desired as it affects the conductivity of the semiconductor and induces defects in the dielectrics.

Table 1 compares various growth techniques and how they affect NWFET output characteristics. Chemical vapour deposition (CVD) is the most popular technique for bottom-up nanowire processes. There are two growth techniques classified under CVD which are vapour-liquid-solid (VLS) and vapour-solid (VS) deposition techniques. CVD normally give the highest mobility as they produce crystalline wires with the only flaw being from the catalysts that guide the growth. VS produces better quality nanowires than VLS as it uses no catalysts but instead uses very high temperatures $\left(>900{ }^{\circ} \mathrm{C}\right)$. The problem with VS is that it is usually harder to control the size and morphology of the nanowires.

Table 1 also shows that atomic layer deposition (ALD) is an attractive technique because it deposits high quality films at low temperatures between $120^{\circ} \mathrm{C}$ and $210{ }^{\circ} \mathrm{C}$ [42], [45]. The problem with ALD is that it has only this window for good quality conducting films. At temperatures below $120^{\circ} \mathrm{C}$ the deposition can be incomplete or experience condensation depending on growth rate. At temperatures above $210{ }^{\circ} \mathrm{C}$ the deposition tends to experience desorption or it decomposes towards CVD deposition. Nonetheless, it is one of the best techniques toward growing films close to epitaxial growth (crystallinity is achievable whereas uniformity is still difficult to achieve) [42], [45]. The tool has shown potential by achieving high values of field effect mobility $>30 \mathrm{~cm}^{2} / \mathrm{Vs}$ with excellent crystallinity.

\subsection{Native point defects}

There are three (3) types of defects in a crystal lattice: point defects, area defects, and volume defects. Point defects which are caused by native elements and impurities are the major problem for $\mathrm{ZnO}$ semiconductor. Native point defects for $\mathrm{ZnO}$ include the following: zinc interstitial $\left(\mathrm{Zn}_{\mathrm{i}}\right)$, zinc antisite $\left(\mathrm{Zn}_{\mathrm{o}}\right)$, zinc vacancy $\left(\mathrm{V}_{\mathrm{Zn}}\right)$, oxygen interstitial $\left(\mathrm{O}_{\mathrm{i}}\right)$, oxygen antisite $\left(\mathrm{O}_{\mathrm{Zn}}\right)$, and oxygen vacancy $\left(\mathrm{V}_{\mathrm{o}}\right)$. Over the years, a lot of research advocated them as the major cause for the n-type behaviour. Oxygen defects are seen as the main contributors toward the n-type behaviour [3], [15]. There are some researchers [1]-[4] who hypothesise that impurities (not the native point defects) are the main cause of the n-type behaviour because they tend to be shallow donors whereas $\mathrm{Zn}$ and $\mathrm{O}_{2}$ defects tend to be deep donors [1]-[4]. The two theories have not been proven so currently the main cause of the natural n-type behaviour of $\mathrm{ZnO}$ [1]-[4] is not certain.

\subsection{Deep donors verses shallow donors- $\mathrm{ZnO}$}

$\mathrm{ZnO}$ impurities (foreign atoms) are normally incorporated in the crystal structure of the semiconductor. There are two reasons of impurity incorporation: they can either be unintentionally introduced due to lack of control during growth processes or they are intentionally added to increase the number of free carriers in the semiconductor. Impurities in the $\mathrm{ZnO}$ should have the ability to be ionized; which is desirable as it increases conductivity. This means that the impurity atoms should be able to give off electrons to the conduction band. If the impurities were acceptors- they should be able to give off holes to the valence band [3], [16]. 
Conduction band

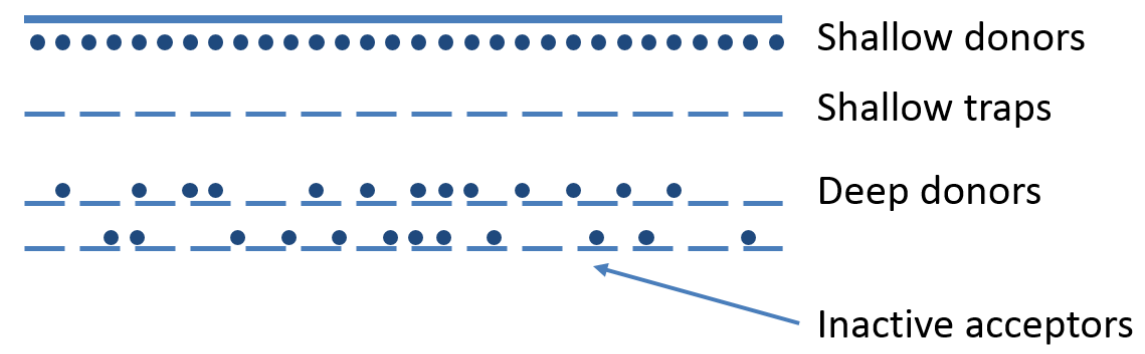

\section{Valence band}

Fig. 2 Shallow verses deep donors [1]-[4]

Table 1 Summary of various methods used for the production of 1-D $\mathrm{ZnO}$ nanostructures, adopted from [25]

\begin{tabular}{|c|c|c|c|c|c|c|c|c|}
\hline No & $\begin{array}{l}\text { Processing } \\
\text { Route }\end{array}$ & $\begin{array}{l}\text { Synthesis } \\
\text { Method }\end{array}$ & $\begin{array}{c}\text { Starting } \\
\text { Materials }\end{array}$ & $\begin{array}{l}\text { Synthesis } \\
\text { Temp. }\left({ }^{\circ} \mathbf{C}\right)\end{array}$ & Morphology & $\begin{array}{c}\text { Diameter } \\
\text { of } \mathrm{ZnO} \\
\text { nanostructure }\end{array}$ & $\begin{array}{c}\text { Length } \\
\text { of } \mathrm{ZnO} \\
\text { nano- } \\
\text { structure } \\
\end{array}$ & Ref. \\
\hline 1 & \multirow{8}{*}{$\begin{array}{c}\text { Vapor- } \\
\text { phase } \\
\text { processing } \\
\text { route }\end{array}$} & \multirow[t]{3}{*}{$\begin{array}{l}\text { Thermal } \\
\text { evaporation }\end{array}$} & $\mathrm{Zn}$ metal, O2, Ar & $650-670$ & Nanowire & $100 \mathrm{~nm}$ & $\begin{array}{l}\text { Several } \\
\text { microns }\end{array}$ & {$[26]$} \\
\hline 2 & & & $\mathrm{Zn}$ metal pellets, $\mathrm{O} 2, \mathrm{Ar}$ & 900 & Nanowire & $20 \mathrm{~nm}$ & - & [27] \\
\hline 3 & & & $\mathrm{Zn}$ powder, $\mathrm{O} 2, \mathrm{Ar}$ & 600 & Nanowire & $80 \mathrm{~nm}$ & $1 \mu \mathrm{m}$ & [28] \\
\hline 4 & & $\begin{array}{l}\text { Vapor-phase } \\
\text { transport }\end{array}$ & $\begin{array}{l}\mathrm{ZnO} \text { powder, graphite, } \\
\text { Cu catalyst }\end{array}$ & 930 & $\begin{array}{c}\text { Hierarchical } \\
\text { dendrite }\end{array}$ & $60-800 \mathrm{~nm}$ & - & {$[29]$} \\
\hline 5 & & \multirow[t]{2}{*}{ Aerosol } & \multirow[t]{2}{*}{$\mathrm{Zn}$ powder, $\mathrm{N}_{2}$ gas } & \multirow[t]{2}{*}{$500-750$} & Fiber-mat & $100-300 \mathrm{~nm}$ & - & \multirow[t]{2}{*}[30]{} \\
\hline 6 & & & & & Cauliflower & $20-30 \mathrm{~nm}$ & - & \\
\hline 7 & & RF sputtering & $\begin{array}{l}\mathrm{ZnO} \text { deposited over } \mathrm{Pt} \\
\text { sputtered interdigitated } \\
\text { alumina substrate }\end{array}$ & - & Nanobelt & - & $\begin{array}{l}\text { Few } \\
\text { micrometer }\end{array}$ & {$[31]$} \\
\hline 8 & & $\begin{array}{l}\text { Molecular beam } \\
\text { epitaxy }\end{array}$ & $\begin{array}{c}\text { Zn metal, O3/O2 plasma } \\
\text { discharge, Au coated } \\
\text { substrate }\end{array}$ & 600 & Nanorod & $50-150 \mathrm{~nm}$ & $2-10 \mu \mathrm{m}$ & {$[32]$} \\
\hline 9 & \multirow{3}{*}{$\begin{array}{c}\text { Solid-state } \\
\text { processing } \\
\text { route }\end{array}$} & $\begin{array}{l}\text { Carbothermal } \\
\text { Reduction }\end{array}$ & $\begin{array}{l}\text { ZnO powder, graphite } \\
\text { powder, Ar gas flow, Au } \\
\text { coated silicon substrate }\end{array}$ & $900-925$ & Nanowire & $80-120 \mathrm{~nm}$ & $10-20 \mu \mathrm{m}$ & $\begin{array}{c}{[33]} \\
{[34]}\end{array}$ \\
\hline 10 & & \multirow{2}{*}{$\begin{array}{l}\text { Solid-state } \\
\text { Chemical } \\
\text { reaction }\end{array}$} & \multirow[t]{2}{*}{$\begin{array}{c}\mathrm{ZnCl}_{2}, \mathrm{NaOH} \\
\text { polyethylene } \mathrm{Glycol} \\
\mathrm{Na}_{2} \mathrm{WO}_{4} \cdot 2 \mathrm{H}_{2} \mathrm{O}\end{array}$} & \multirow[t]{2}{*}{ RT } & \multirow[t]{2}{*}{ Nanorod } & $40-60 \mathrm{~nm}$ & $200 \mathrm{~nm}$ & {$[35]$} \\
\hline 11 & & & & & & $20-40 \mathrm{~nm}$ & $100 \mathrm{~nm}$ & \\
\hline 12 & \multirow{7}{*}{$\begin{array}{c}\text { Wet } \\
\text { processing } \\
\text { route }\end{array}$} & \multirow[t]{5}{*}{ Hydrothermal } & 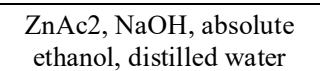 & 180 & Nanorod & - & - & {$[36]$} \\
\hline 13 & & & $\begin{array}{l}\mathrm{Zn}(\mathrm{CH} 3 \mathrm{COO}) 2 \cdot 2 \mathrm{H} 2 \mathrm{O}, \\
\mathrm{C} 6 \mathrm{H} 8 \mathrm{O} 7 \cdot \mathrm{H} 2 \mathrm{O}, \text { absolute } \\
\text { ethanol, distilled water }\end{array}$ & 400 & $\begin{array}{c}\text { Nanorod } \\
\text { (vertically } \\
\text { aligned) }\end{array}$ & $50 \mathrm{~nm}$ & $500 \mathrm{~nm}$ & {$[37]$} \\
\hline 14 & & & $\begin{array}{l}\mathrm{Zn}\left(\mathrm{NO}_{3}\right)_{2} \cdot 6 \mathrm{H}_{2} \mathrm{O}, \mathrm{NaOH}, \\
\text { cetyltrimethyl ammonium } \\
\text { bromide, ethanol }\end{array}$ & 120 & Nanorod & - & - & {$[38]$} \\
\hline 15 & & & $\begin{array}{c}\mathrm{Zn}\left(\mathrm{NO}_{3}\right)_{2} \cdot 6 \mathrm{H}_{2} \mathrm{O}, \mathrm{NaOH}, \\
\text { cyclohexylamine, ethanol, } \\
\text { water }\end{array}$ & 200 & Nanorod & $150-200 \mathrm{~nm}$ & $2 \mu \mathrm{m}$ & [39] \\
\hline 16 & & & $\begin{array}{c}\mathrm{Zn}\left(\mathrm{SO}_{4}\right) \cdot 7 \mathrm{H}_{2} \mathrm{O}, \mathrm{NH}_{4} \mathrm{OH} \\
\text { deionized water }\end{array}$ & $75-95$ & Nanorod & - & - & [40] \\
\hline 17 & & ALD & $\operatorname{DEZ}\left(\mathrm{Zn}\left(\mathrm{C}_{2} \mathrm{H}_{5}\right)_{2}\right), \mathrm{H}_{2} \mathrm{O}$ & - & Nanowire & $70-100 \mathrm{~nm}$ & $5 \mu \mathrm{m}$ & {$[41]$} \\
\hline 18 & & Plasma ALD & $\operatorname{DEZ}\left(\mathrm{Zn}\left(\mathrm{C}_{2} \mathrm{H}_{5}\right)_{2}\right), \mathrm{O}_{2}$ & $150-190$ & Nanowire & $36-100 \mathrm{~nm}$ & $2-20 \mu \mathrm{m}$ & {$[42]$} \\
\hline
\end{tabular}


Donor Impurities for the n-type $\mathrm{ZnO}$ can either be shallow or deep. Fig 2 shows shallow donors compared to deep donors. Shallow impurities require little energy to ionize (this is energy typically around the thermal energy or less). These donor impurities possess energy close to the band edge the extra valence electron of these impurities are loosely bound and occupy effective-mass states near the conduction band maximum- CBM- at low temperatures. Deep impurities on-the-other-hand require energy greater that the thermal energy to ionize. These donor impurities possess energy far from the band edge (CBM) making them very hard to ionize. Their presence within the semiconductor tends to contribute only a small fraction of free carriers. Deep donors are also called traps because they act as effective recombination centres in which electrons and holes fall and annihilate each other. Grain boundaries (GB) are main source of deep state impurities and they adversely affect transistor performance. $\mathrm{ZnO}$ is a wide Bandgap material and research suggests [3], [4], [16] that there exists possible deep-level traps in GBs. The examples of deep donors are $\mathrm{Zn}$ and O ions. Zn acts as a deep donor when there is a vacancy and $\mathrm{O}$ acts as a deep donor in any defect state. An example of a shallow donor is the $\mathrm{H}$ ion.

\subsection{Top-down fabrication of ZnO nanowire FETs}

There are four main methods capable of producing nanometer features using top-down approaches: UV stepper lithography, e-beam lithography [68], focused ion-beam lithography [69] and spacer method [45], [70]. UV lithography is the standard industrial method for fabricating nano devices. Ebeam and focused ion-beam lithography are often used and can pattern devices down to $5 \mathrm{~nm}$, but the equipment is very expensive and the pattern writing is very slow. These two instruments resemble scanning electron microscope (SEM) in terms of operation. Whereas SEM is used to focus a beam of electrons to image samples within a chamber, these instruments are used to create patterns on the samples. The difference between e-beam and focused ion-beam is that the latter uses an ion beam to pattern wafers and hence does not require photoresist. Their advantage over optical UV lithography is the small features they reach. For low cost applications such as biosensors, the problem with these two methods is that they are expensive.

The spacer technique is a low cost fabrication method for fabricating nanowires. It was first reported in 2005 by H. Ge, et al., [71] and other researchers [41], [72], [73] have since carried it forward. The technique has great potential in shaping nanometer features using conventional, low cost photolithography. Fig. 3 shows the concept of the spacer technique. It uses first anisotropic etch to create a vertical pillar on an insulating layer $\left(\mathrm{SiO}_{2}\right)$, then after deposition of a semiconductor layer $(\mathrm{ZnO})$ and a second anisotropic etch to create nanowires made up of the semiconductor layer. This method allows nanowire features with controllable dimensions to be developed. The ICP tool is usually used for anisotropic etching and produces surface roughness less than $<1.5 \mathrm{~nm}$. Other tools such as RIE and ion beam etch produce roughness greater than $>5 \mathrm{~nm}$. The fabrication process for the complete ZnO NWFET structure is as outlined in [134].

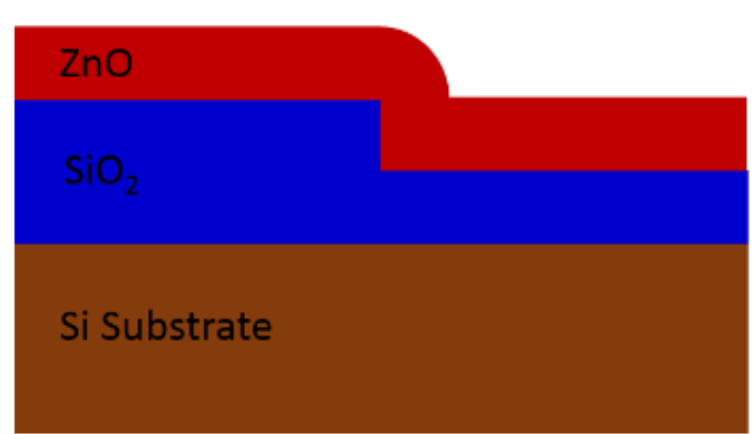

(a)

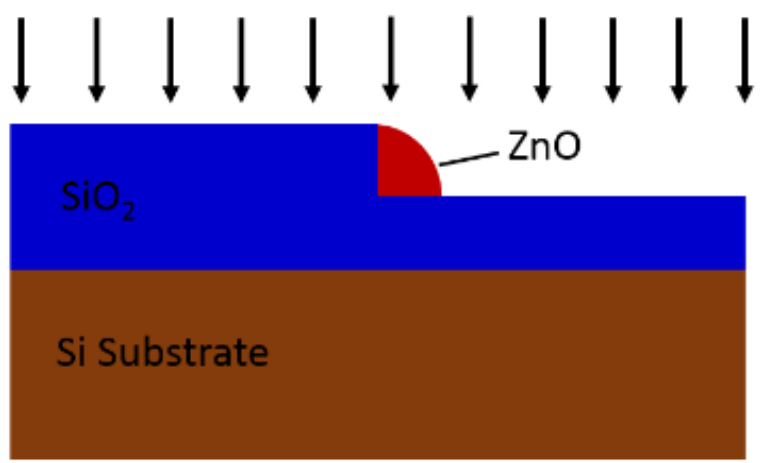

(b)

Fig. 3 Novel spacer technique used to pattern nanowire features. Cross-sectional schematic of nanowire formation (a) before dry etch (b) after dry etch. [42] 


\section{Background on FETs}

The $\mathrm{ZnO}$ field effect transistor (FET) has been around for decades. The success of the device in meeting the technological demands has largely been dominated by the shrinking size of its physical geometry. It has an advantage as a junctionless (no p-n junctions) FETs compared to conventional FETs [17], [21]-[24], [43], [44], [46], [47]. There has been an introduction of new materials and heterojunction structures developed so as to move away from conventional silicon devices. High-K dielectrics have been introduced to replace the conventional $\mathrm{SiO}_{2}$ which should help maintain acceptable dielectric thicknesses while keeping gate leakage currents low [17], [21] -[24], [43], [44], [46], [47].

Even with so many improvements being made to the device, the limits of FET scaling are approaching. The thickness of the oxide $\left(\mathrm{t}_{\mathrm{ox}}\right)$ cannot be less than $1 \mathrm{~nm}$ due to high tunnelling current and significant operational variation. The substrate doping is also very high which creates leakage and tunnelling currents that are unacceptable to device operation.

\subsection{ZnO thin film transistors (TFTs)}

TFTs have also been fabricated using $\mathrm{ZnO}$, mainly thin film transistors for application in displays. Fig. 4 compares twenty ZnO TFTs fabricated by different authors [44], [46], [48]-[65] using a variety of fabrication methods over the last five years. The graph is a plot of field effect mobility versus subthreshold slope which are two of the main parameters that describe the performance and efficiency of a device. The best device was fabricated by Bayraktaroglu, et al. [64] with a $\mathrm{SiO}_{2}$ insulator and pulsed laser deposited $\mathrm{ZnO}$ active channel layer. The device had a field effect mobility $110 \mathrm{~cm}^{2} / \mathrm{Vs}$ and an excellent subthreshold gate voltage swing of $109 \mathrm{mV} /$ decade. This value of mobility is much higher than the value of around $1 \mathrm{~cm}^{2} / \mathrm{Vs}$ that is typically achieved with amorphous silicon TFTs in production displays. It is clear therefore that ZnO TFTs have considerable potential for application in high performance displays.

\subsection{Nanowire field effect transistors (FETs)}

Emerging non-planar devices [17], [21] are being researched to prolong the future progress for FETs. Devices based on quasi-one-dimensional nanostructures are still at an embryonic stage from an industrial point of view. These nanostructures include the following: nanowires, nanobelts, nanoribbons, and nanoneedles [66], [67]. This review is interested in nanowire FETs which are also being researched for application in biosensors because the high surface to volume ratio provides high sensitivity.

\subsection{Comparing ZnO NWFETs}

Fig. 5 compares fifteen (15) different ZnO NWFETs fabricated by different authors using a variety of methods [42], [74]-[86]. The graph is plotted with field effect mobility against the subthreshold slope which are two important device parameters that determine ZnO NWFET performance. The nanowires were fabricated using top-down and bottom-up (self-assembled) processes. Self-assembled processes tend to display very high field effect mobility which is normally above $200 \mathrm{~cm}^{2} / \mathrm{Vs}$; whereas the top-down have lower mobility values. Most of the top-down fabricated devices have mobility $<1.0 \mathrm{~cm}^{2} / \mathrm{Vs}$ with around three papers giving a mobility $>10.0 \mathrm{~cm}^{2} / \mathrm{Vs}$. The difference in the mobility may be due to the fact that self-assembled nanowires are single-crystal, whereas topdown nanowires are polycrystalline. Nonetheless, top-down techniques are desirable as they currently pave way for mass production and will be pursued in this research investigation.

\section{Biosensors}

A biosensor is defined by the International Union of Pure and Applied Chemistry (IUPAC) as "a self-contained integrated device that is capable of providing specific quantitative or semi-quantitative analytical information using a biological recognition element (biochemical receptor), which is retained in contact direct with a transduction element" [87]. A biosensor is a "more-than-Moore device" because it incorporates functionalities that do not necessarily scale according to Moore's law. 
Under the roadmap, the device falls under the category of sensors and actuators. Other categories include analogue/RF, passives, HV power and biochips [88], [89].

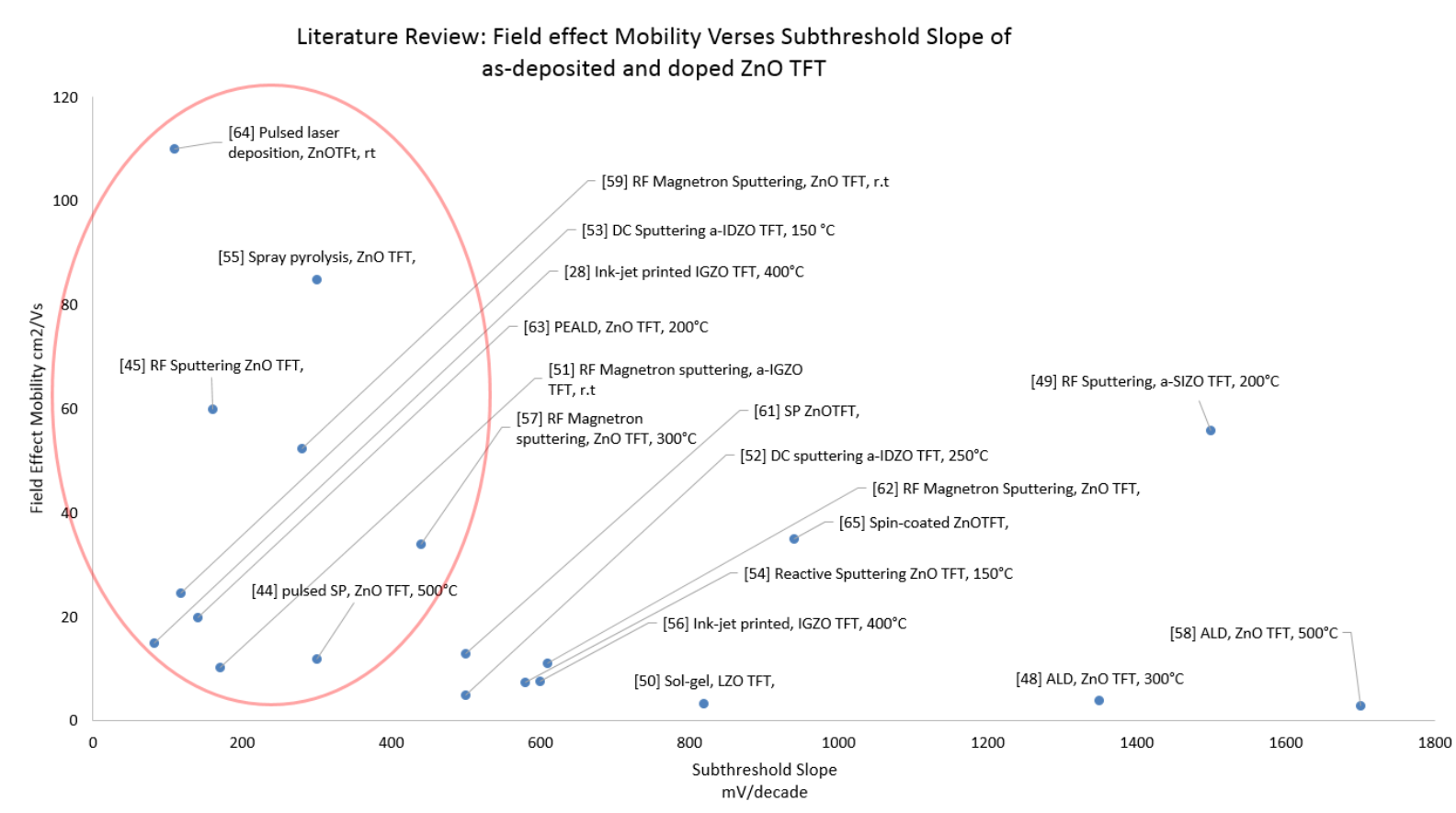

Fig. 4 General literature review on TFTs looking at field effect mobility verses subthreshold slope of as deposited and doped $\mathrm{ZnO}$ films

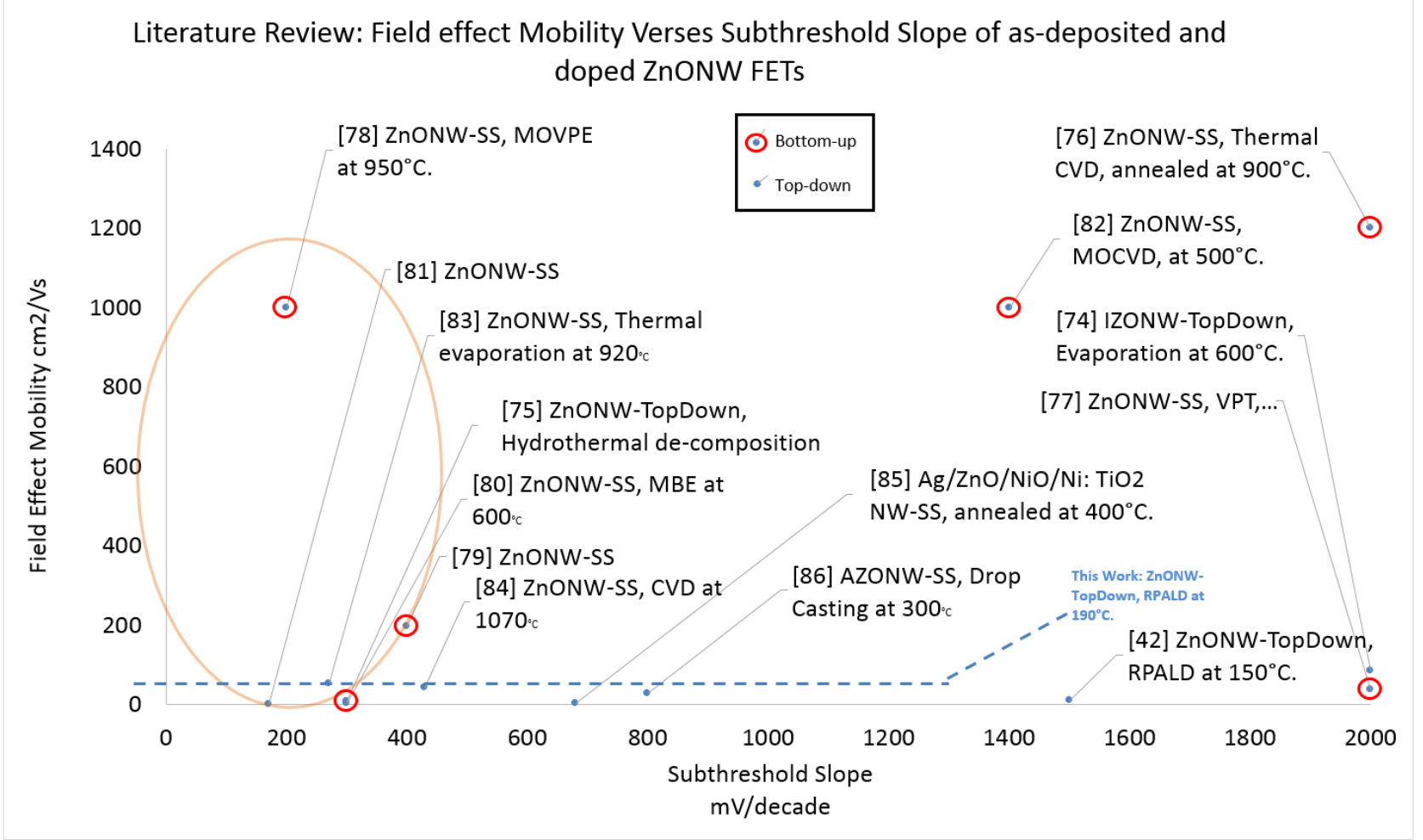

Fig. 5 Literature review on nanowire FETs looking at field effect mobility verses subthreshold slope of as-deposited and doped $\mathrm{ZnO}$ films 


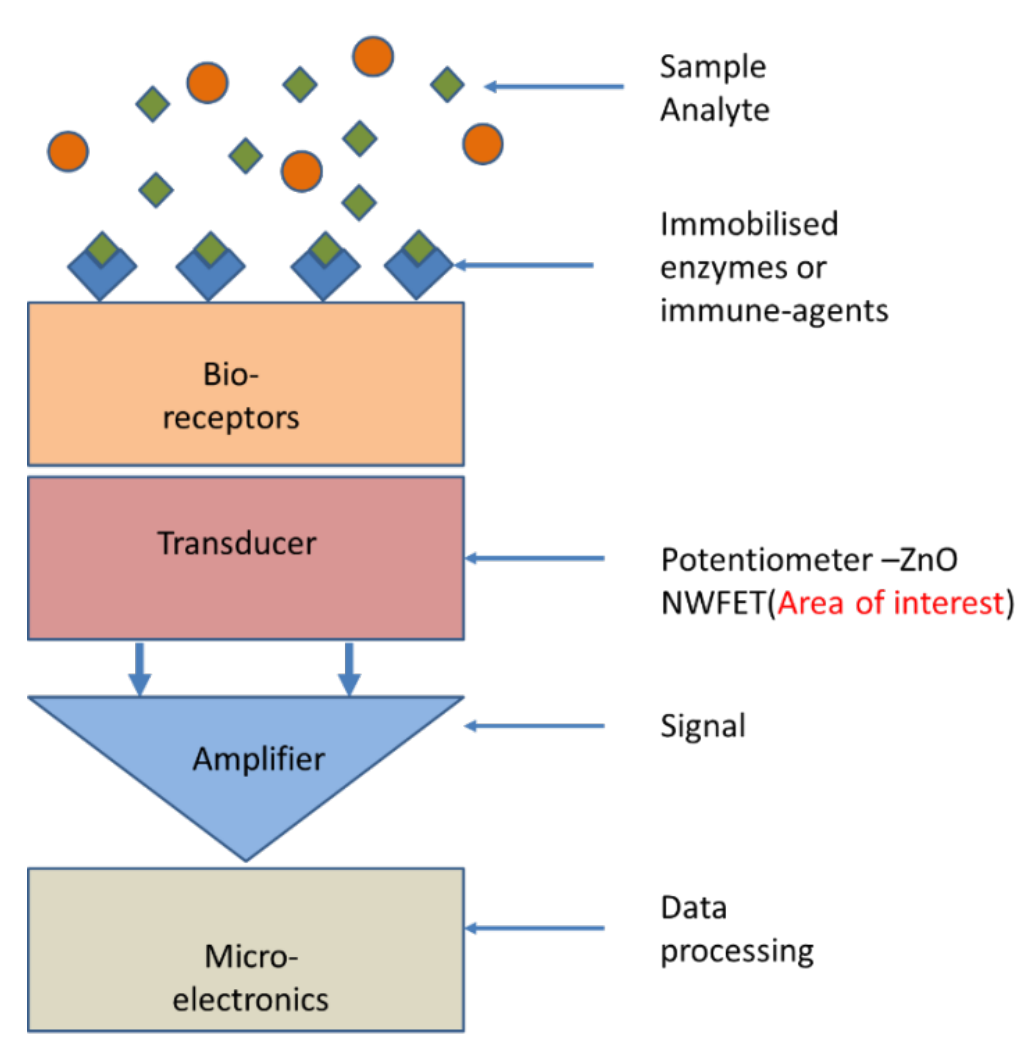

Fig. 6 Typical structure of a biosensor. The bio-molecules are contained within an analytic solution that attach themselves to immobilised enzymes or immune-agents on the receptors. The transducer then converts the energy signal produced into an electrical signal which is then transmitted for data processing [42]

Fig. 6 shows a typical structure of a biosensor [90]-[92]. The bio-molecules are contained within an analytic solution that attach themselves to immobilised enzymes or immune-agents on the linkers. Linkers in turn are attached to the transducer. The transducer then converts the charge on the analyte into an electrical signal which is then transmitted for data processing. Biosensors can be considered as part of the research field known as 'chemical sensors' in that a biological mechanism is used for analyte detection within an analyte solution [93]-[95]. Quasi-one-dimensional nanostructures have a greater surface-to-volume ratio compared to planar structures and are therefore expected to be more sensitive than planar sensors [93]-[95].

Nanowires are the same as nanorods. The words can be used interchangeably [80]. These have received enormous attention due to their suitable properties for designing novel nanoscale biosensors. For example, the dimensions of $\sim 1-100 \mathrm{~nm}$ are similar to those of many biological entities, such as nucleic acids, proteins, viruses, and cells [79]. In addition, the high surface-to-volume ratios for nanomaterials allows a large proportion of atoms in the bio-analyte to be located at or close to the surface. Moreover, some nanowire materials have surfaces that can easily be chemically modified which makes them significant candidates for biosensors [79], [80]. There are a number of nanostructure-based electrical biosensors which include: single-wall carbon nanotubes (SWCNT), nanowires, nanogaps, nanochannels, and nano-electromechanical (NEM) devices. The project will focus on nanowire-based devices as they have considerable potential for electrical biosensing that offer the possibility of portable assays in a variety of point-of-care environments [70], [90], [96].

\subsection{Silicon biosensors}

Over the past decade, silicon nanowires have been the most researched for application as biochemical sensors [97]-[108]. Silicon nanowires are of interest for a number of reasons, for example, the material is well known and is compatible with CMOS integrated circuits for the development of sensor systems [97]-[108]. The nanowire is expected to have high surface-to-volume ratios which gives high sensitivity and the electrical sensing will give real-time label-free detection without the use of expensive optical components. Mass manufacturing is also a main advantage for 
silicon and is critically important for nanowire biosensor applications because of the widespread uptake of biosensors in 'point-of-care' settings, the biosensor needs to be disposable [97]-[108].

A number of fabrication methods are well established for silicon nanowires which utilise both bottom-up and top-down methods (These methods are called hybrids). It still remains that bottom-up techniques have the advantage of simplicity [97]-[108]. Bottom-up methods are still limited due to the alignment problem. The hybrid methods require further nanowire technologies to achieve alignment, such as electric field or fluid-flow-assisted nanowire positioning to locate the nanowires between lithographically defined source and drain electrodes. The technique is interpreted as a hybrid between bottom-up and top-down. Top-down methods overcome these problems, and several researchers have used advanced lithography techniques to fabricate single-crystal silicon nanowires on silicon-on-insulator (SOI) substrates. SOI wafers are expensive and to overcome the problem some researchers [109] have devised alternatives to SOI. The electrical output characteristics of silicon nanowires are good and they are well-suited for biosensing applications. The sensitivity range for most silicon-nanowire based biosensors is between 50 and $400 \mathrm{mV}$ [97]-[108].

Table 2 Summary of characteristics for various 1-D ZnO biosensors, adopted from [111]

\begin{tabular}{|c|c|c|c|c|c|c|c|}
\hline No & $\begin{array}{l}\text { Reference } \\
\text { Electrode }\end{array}$ & $\begin{array}{l}\text { Type of } \\
\text { Sensor }\end{array}$ & Channel Material & $\begin{array}{c}\mathrm{ZnO} \text { Fabrication } \\
\text { Process }\end{array}$ & $\begin{array}{l}\text { LOD } \\
(\mu \mathrm{M})\end{array}$ & $\begin{array}{l}\text { Response } \\
\text { time (s) }\end{array}$ & Ref. \\
\hline 1 & $\mathrm{Au}$ & Biosensor & ZnO Nanorod array & Hydro-thermal & 10 & $<5$ & [119] \\
\hline 2 & ITO & Biosensor & $\mathrm{ZnO}$ nanotube array & $\begin{array}{c}\text { Hydro-thermal/ } \\
\text { chemical }\end{array}$ & 10 & $<6$ & {$[120]$} \\
\hline 3 & $\mathrm{Au}$ & Biosensor & Tetrapod like $\mathrm{ZnO}$ & CVD & 4 & 6 & {$[121]$} \\
\hline 4 & $\begin{array}{c}\text { Glass } \\
\text { capillary }\end{array}$ & Biosensor & $\mathrm{ZnO}$ nanoflakes & Hydro-thermal & 0.5 & $<4$ & {$[123]$} \\
\hline 5 & GCE & Biosensor & Fork-like $\mathrm{ZnO}$ & Annealing & 0.3 & 3 & {$[124]$} \\
\hline 6 & $\mathrm{Au}$ & Biosensor & Comb-like $\mathrm{ZnO}$ & CVD & 20 & $<10$ & {$[113]$} \\
\hline 7 & $\mathrm{Ti}$ & Biosensor & $\mathrm{ZnO} / \mathrm{C}$ Nanorod array & Hydro-thermal & 1 & 4 & {$[125]$} \\
\hline 8 & ITO & Biosensor & $\mathrm{ZnO} / \mathrm{Cu}$ array matrix & Hydro-thermal & 40 & $<6$ & {$[126]$} \\
\hline 9 & GCE & Biosensor & $\mathrm{ZnO} / \mathrm{Au}$ nanorods & Hydro-thermal & 0.01 & $<5$ & {$[128]$} \\
\hline 10 & $\mathrm{Pt}$ & Biosensor & $\mathrm{ZnO} / \mathrm{NiO}$ nanorods & Hydro-thermal & 2.5 & $<5$ & {$[129]$} \\
\hline
\end{tabular}

Table 3 Summary of characteristics for various 1-D Si biosensors, adopted from [110]

\begin{tabular}{|c|c|c|c|c|c|c|c|}
\hline No & $\begin{array}{c}\text { Reference } \\
\text { Electrode }\end{array}$ & $\begin{array}{c}\text { Type of } \\
\text { Sensor }\end{array}$ & Channel Material & $\begin{array}{c}\text { ZnO Fabrication } \\
\text { Process }\end{array}$ & $\begin{array}{c}\text { LOD } \\
(\mathrm{pM})\end{array}$ & $\begin{array}{c}\text { Response } \\
\text { time (s) }\end{array}$ & Ref. \\
\hline 1 & $\begin{array}{c}\text { No } \\
\text { reference } \\
\text { electrode }\end{array}$ & Biosensor & Si NW & $\begin{array}{c}\text { nanocluster- } \\
\text { mediated } \\
\text { vapor-liquid- } \\
\text { solid growth } \\
\text { method }\end{array}$ & 10 & $<10$ & {$[97]$} \\
\hline 2 & $\mathrm{Au}$ & Biosensor & Si NW & $\begin{array}{c}\text { Chemical vapour } \\
\text { deposition }\end{array}$ & 0.002 & $<10$ & {$[98]$} \\
\hline 3 & $\begin{array}{c}\text { platinum } \\
\text { wire }\end{array}$ & Biosensor & Si NW & SNAP technique & 10 & $<10$ & {$[101]$} \\
\hline 4 & none & Biosensor & Si NW & $\begin{array}{c}\text { reactive-ion } \\
\text { etching (RIE) }\end{array}$ & 0.01 & $<10$ & {$[106]$} \\
\hline 5 & none & Biosensor & Si NW & $\begin{array}{c}\text { synthesized by } \\
\text { chemical vapor } \\
\text { deposition }\end{array}$ & 100 & $<10$ & {$[135]$} \\
\hline
\end{tabular}




\subsection{Comparing $\mathrm{ZnO}$ nanowire biosensors}

$\mathrm{ZnO}$ is investigated as it is expected to be more sensitive than Si due to its wider band-gap [109]. This is observed by comparing Table 2 with Table 3 . $\mathrm{ZnO}$ devices show results comparable to silicon devices; especially looking at response time and limit of detection. It is required that biosensors should have the liquid reference electrode. There are many different types of $\mathrm{ZnO}$ nanostructures being used for sensing application and Table 2 compares the $\mathrm{ZnO}$ nanostructures such as nanotetrapods, nanocombs and nanorods used for biosensing [110], [111]. Nanotetrapods [112] are like nanorods but with four single crystalline legs. Most of the $\mathrm{ZnO}$ devices were synthesized by vapour-phase method and then transferred on Au electrode to form a multi-terminal network for the sensor receptors. Like all other bottom-up $\mathrm{ZnO}$ nanostructures discussed here, they are transferred to a surface of a working electrode to form a thin layer to modify the transducer. The devices have low sensitivity but the nanotetrapods exhibit good detection limit down to $\sim 1.0 \mathrm{nM}$. The researchers [112] did not explained why the nanostructures possess low sensitivity but its three dimensional features have the potential for multi-terminal communication applications [112].

In nanocombs [113] design, each comb has between 3 to 10 rods connected to one another by a single rod. $\mathrm{ZnO}$ nanocombs were used as the channel for sensing glucose [113] and as label-free uric acid biosensor based on uricase [114]. The functionalised $\mathrm{ZnO}$ nanorods showed thermal stability, anti-interference capability and direct electron transfer (DET) between enzyme electroactive sites and external electrodes. The activity of the enzyme and the sensitivity can be increased by introducing a lipid film between the channel and the enzyme. Another uric acid biosensor [115] example is based on uricase-functionalised $\mathrm{ZnO}$ nanoflakes, which was hydrothermally prepared at low temperatures on Au-coated glass. The sensor produced a sensitivity based on sub-threshold slope of $\sim 66 \mathrm{mV} /$ decade. Bottom-up ZnO nanorods [116] were also used as lactate oxidase (LOD) biosensor using glutaraldehyde cross-linkers. The device had a sub-threshold sensitivity of $\sim 41 \mathrm{mV} /$ decade, with maximum detection of $0.1 \mu \mathrm{M}$. To test for cholesterol, porous $\mathrm{ZnO}$ mirco-tubes [117] were constructed using 3D assembled porous flakes. $\mathrm{ZnO}$ nanorods [118] were grown on Ag electrode to make a cholesterol sensor.

\section{Conclusion}

Most researchers use bottom-up approaches to fabricate the $\mathrm{ZnO}$ biosensors because of the straightforward synthesis process. However, these bottom-up devices have variable electrical performance due to the lack of geometrical dimension control and addressing the nanostructures for sensing application. So far, there is limited research reported on top-down $\mathrm{ZnO}$ biosensors and previous work demonstrated the viability of top-down ZnO NWFET for biosensor applications. In the work, however, there was no passivation layer on the $\mathrm{ZnO}$ nanowires, which led to dissolution of the material. This made the device unstable and the sensing results were not reproducible. There exists a need to develop a passivating layer technology and optimise the fabrication process for biosensor applications. That way, reliable measurement of sensitivity for the non-specific and specific sensing of lysozyme and bovine serum albumin (BSA) can be achieved.

\section{Acknowledgment}

N.M.J. Ditshego would like to acknowledge the Botswana International University of Science and Technology (BIUST) for supporting his doctoral studies and the Southampton Nanofabrication Centre for the experimental work. The authors would like to acknowledge EPSRC EP/K502327/1 grant support. 


\section{References}

[1] C. Klingshirn, J. Fallert, H. Zhou, J. Sartor, C. Thiele, F. Maier-Flaig, D. Schneider, and H. Kalt, "65 years of ZnO research - old and very recent results," Phys. Status Solidi, vol. 247, no. 6, pp. 1424-1447, Apr. 2010.

[2] U. Özgür, Y. I. Alivov, C. Liu, A. Teke, M. A. Reshchikov, S. Doğan, V. Avrutin, S.-J. Cho, and H. Morkoç, "A comprehensive review of $\mathrm{ZnO}$ materials and devices," J. Appl. Phys., vol. 98, no. 4, p. 041301, 2005.

[3] M. D. McCluskey and S. J. Jokela, "Defects in ZnO," J. Appl. Phys., vol. 106, no. 7, p. 071101, 2009.

[4] A. Janotti and C. G. Van de Walle, "Fundamentals of zinc oxide as a semiconductor," Reports Prog. Phys., vol. 72, no. 12, p. 126501, Dec. 2009.

[5] G. Wang, S. Chu, N. Zhan, H. Zhou, and J. Liu, "Synthesis and characterization of Ag-doped p-type ZnO nanowires," Appl. Phys. A, vol. 103, no. 4, pp. 951-954, Jun. 2011.

[6] A. Tsukazaki, A. Ohtomo, T. Onuma, M. Ohtani, T. Makino, M. Sumiya, K. Ohtani, S. F. Chichibu, S. Fuke, Y. Segawa, H. Ohno, H. Koinuma, and M. Kawasaki, "Repeated temperature modulation epitaxy for p-type doping and light-emitting diode based on $\mathrm{ZnO}$," Nat. Mater., vol. 4, no. 1, pp. 42-46, Jan. 2005.

[7] M. S. Oh, D. K. Hwang, K. Lee, S. Im, and S. Yi, "Low voltage complementary thin-film transistor inverters with pentacene-ZnO hybrid channels on Al Ox dielectric," Appl. Phys. Lett., vol. 90, no. 17, pp. 173511-3, Apr. 2007.

[8] J.-H. Choi, S. W. Lee, J. P. Kar, S. N. Das, J. Jeon, K.-J. Moon, T. Il Lee, U. Jeong, and J.-M. Myoung, "Random network transistor arrays of embedded $\mathrm{ZnO}$ nanorods in ion-gel gate dielectric," Journal of Materials Chemistry, vol. 20, no. 35. p. 7393, 2010.

[9] L. Dunlop, A. Kursumovic, and J. L. MacManus-Driscoll, "Reproducible growth of p-type $\mathrm{ZnO}: \mathrm{N}$ using a modified atomic layer deposition process combined with dark annealing," Appl. Phys. Lett., vol. 93, no. 17, p. 172111, 2008.

[10] J. Huang, S. Chu, J. Kong, L. Zhang, C. M. Schwarz, G. Wang, L. Chernyak, Z. Chen, and J. Liu, "ZnO p - n Homojunction Random Laser Diode Based on nitrogen-doped nanowires," Adv. Opt. Mater., vol. 1, no. 2, pp. 179-185, Feb. 2013.

[11] M. Kumar, J. P. Kar, I. S. Kim, S. Y. Choi, and J. M. Myoung, "Fabrication of As-doped ptype $\mathrm{ZnO}$ thin film and $\mathrm{ZnO}$ nanowire inserted p-n homojunction structure," Appl. Phys. A Mater. Sci. Process., vol. 97, no. 3, pp. 689-692, Nov. 2009.

[12] G. D. Yuan, W. J. Zhang, J. S. Jie, X. Fan, J. A. Zapien, Y. H. Leung, L. B. Luo, P. F. Wang, C. S. Lee, and S. T. Lee, "p-type ZnO nanowire arrays," Nano Lett., vol. 8, no. 8, pp. 25912597, Aug. 2008.

[13] S. N. Cha, J. E. Jang, Y. Choi, G. A. J. Amaratunga, G. W. Ho, M. E. Welland, D. G. Hasko, D.-J. Kang, and J. M. Kim, "High performance ZnO nanowire field effect transistor using selfaligned nanogap gate electrodes," Appl. Phys. Lett., vol. 89, no. 26, Dec. 2006.

[14] F. M. Li, G.-W. Hsieh, S. Dalal, M. C. Newton, J. E. Stott, P. Hiralal, A. Nathan, P. A. Warburton, H. E. Unalan, P. Beecher, A. J. Flewitt, I. Robinson, G. Amaratunga, and W. I. Milne, "Zinc Oxide Nanostructures and High Electron Mobility Nanocomposite Thin Film Transistors," IEEE Trans. Electron Devices, vol. 55, no. 11, pp. 3001-3011, Nov. 2008.

[15] T. E. Murphy, J. O. Blaszczak, K. Moazzami, W. E. Bowen, and J. D. Phillips, "Properties of electrical contacts on bulk and epitaxial n-type ZnO," J. Electron. Mater., vol. 34, no. 4, pp. 389-394, Apr. 2005. 
[16] D.-J. Lee, J.-Y. Kwon, S.-H. Kim, H.-M. Kim, and K.-B. Kim, "Effect of Al Distribution on Carrier Generation of Atomic Layer Deposited Al-Doped ZnO Films," J. Electrochem. Soc., vol. 158 , no. 5, p. D277, 2011.

[17] D. Hofstetter and H. Morkoc, "ZnO Devices and Applications : A Review of Current Status and Future Prospects," 2010.

[18] R. Triggs, "Display technology explained: A-Si, LTPS, amorphous IGZO, and beyond," (Android Authority), [online] July 2014, http://www.androidauthority.com/amorphous-igzoand-beyond-399778/, (Accessed: 01 March 2015).

[19] J. Hruska, "The perils and promise of high-resolution displays," (Extreme Tech), [online] April 2012, http://www.extremetech.com/electronics/126519-the-perils-and-promise-of-highresolution-displays, (Accessed: 01 March 2015).

[20] S. Anthony, "IGZO display tech finally makes it to mass market: iPad Air now, high-res desktop display soon," (Extreme Tech), [online] November 2013, http://www.extremetech.com/computing/170970-igzo-display-tech-finally-makes-it-to-massmarket-ipad-air-now-high-res-laptops-and-desktops-next, (Accessed: 01 March 2015).

[21] M. A. Riyadi, J. E. Suseno, and R. Ismail, "The Future of Non-planar Nanoelectronics MOSFET Devices: A Review," J. Appl. Sci., vol. 10, no. 18, pp. 2136-2146, Dec. 2010.

[22] J.-S. Park, "The annealing effect on properties of $\mathrm{ZnO}$ thin film transistors with Ti/Pt sourcedrain contact," Journal of Electroceramics, vol. 25, no. 2-4. pp. 145-149, Oct-2010.

[23] E. Engineering, "Amorphous In-Ga-Zn-O Thin Film Transistor for Future Optoelectronics by Tze-Ching Fung," 2010.

[24] Y. Moon, S. Lee, and D. Kim, "Characteristics of ZnO based TFT using La2O3 high-k dielectrics," J. Korean, vol. 55, no. 5, pp. 1906-1909, Nov. 2009.

[25] M. M. Arafat, B. Dinan, S. A. Akbar, and A. S. M. A Haseeb, "Gas sensors based on one dimensional nanostructured metal-oxides: A review," Sensors (Switzerland), vol. 12, no. 6, pp. 7207-7258, Jan. 2012.

[26] O. Lupan, V. V. Ursaki, G. Chai, L. Chow, G. A. Emelchenko, I. M. Tiginyanu, A. N. Gruzintsev, and A. N. Redkin, "Selective hydrogen gas nanosensor using individual $\mathrm{ZnO}$ nanowire with fast response at room temperature," Sensors Actuators B Chem., vol. 144, no. 1, pp. 56-66, Jan. 2010.

[27] Q. Wan, C. L. Lin, X. B. Yu, and T. H. Wang, "Room-temperature hydrogen storage characteristics of ZnO nanowires," Appl. Phys. Lett., vol. 84, no. 1, p. 124, Dec. 2004.

[28] K.-Y. Dong, J.-K. Choi, I.-S. Hwang, J.-W. Lee, B. H. Kang, D.-J. Ham, J.-H. Lee, and B.-K. $\mathrm{Ju}$, "Enhanced $\mathrm{H} 2 \mathrm{~S}$ sensing characteristics of Pt doped $\mathrm{SnO} 2$ nanofibers sensors with micro heater," Sensors Actuators B Chem., vol. 157, no. 1, pp. 154-161, Sep. 2011.

[29] N. Zhang, K. Yu, Q. Li, Z. Q. Zhu, and Q. Wan, "Room-temperature high-sensitivity H[sub 2]S gas sensor based on dendritic $\mathrm{ZnO}$ nanostructures with macroscale in appearance," J. Appl. Phys., vol. 103, no. 10, p. 104305, May 2008.

[30] C. Baratto, G. Sberveglieri, A. Onischuk, B. Caruso, and S. di Stasio, "Low temperature selective NO2 sensors by nanostructured fibres of ZnO," Sensors Actuators B Chem., vol. 100, no. 1-2, pp. 261-265, Jun. 2004.

[31] A. Z. Sadek, S. Choopun, W. Wlodarski, S. J. Ippolito, and K. Kalantar-zadeh, "Characterization of $\mathrm{ZnO}$ Nanobelt-Based Gas Sensor for $\mathrm{H}_{2}, \mathrm{NO}_{2}$ and Hydrocarbon Sensing," IEEE Sens. J., vol. 7, no. 6, pp. 919-924, Jun. 2007. 
[32] H. T. Wang, B. S. Kang, F. Ren, L. C. Tien, P. W. Sadik, D. P. Norton, S. J. Pearton, and J. Lin, "Hydrogen-selective sensing at room temperature with $\mathrm{ZnO}$ nanorods," Appl. Phys. Lett., vol. 86, no. 24, p. 243503, Jun. 2005.

[33] M. H. Huang, Y. Wu, H. Feick, N. Tran, E. Weber, and P. Yang, "Catalytic Growth of Zinc Oxide Nanowires by Vapor Transport," Adv. Mater., vol. 13, no. 2, pp. 113-116, Jan. 2001.

[34] M.-W. Ahn, K.-S. Park, J.-H. Heo, J.-G. Park, D.-W. Kim, K. J. Choi, J.-H. Lee, and S.-H. Hong, "Gas sensing properties of defect-controlled ZnO-nanowire gas sensor," Appl. Phys. Lett., vol. 93, no. 26, p. 263103, Dec. 2008.

[35] Y. Cao, P. Hu, W. Pan, Y. Huang, and D. Jia, "Methanal and xylene sensors based on ZnO nanoparticles and nanorods prepared by room-temperature solid-state chemical reaction," Sensors Actuators B Chem., vol. 134, no. 2, pp. 462-466, Sep. 2008.

[36] C. Wang, X. Chu, and M. Wu, "Detection of $\mathrm{H} 2 \mathrm{~S}$ down to ppb levels at room temperature using sensors based on ZnO nanorods," Sensors Actuators B Chem., vol. 113, no. 1, pp. 320-323, Jan. 2006.

[37] Z. Yang, L.-M. Li, Q. Wan, Q.-H. Liu, and T.-H. Wang, "High-performance ethanol sensing based on an aligned assembly of $\mathrm{ZnO}$ nanorods," Sensors Actuators B Chem., vol. 135, no. 1, pp. 57-60, Dec. 2008.

[38] X. Zhou, J. Li, M. Ma, and Q. Xue, "Effect of ethanol gas on the electrical properties of ZnO nanorods," Phys. E Low-dimensional Syst. Nanostructures, vol. 43, no. 5, pp. 1056-1060, Mar. 2011.

[39] P.-S. Cho, K.-W. Kim, and J.-H. Lee, "NO2 sensing characteristics of $\mathrm{ZnO}$ nanorods prepared by hydrothermal method," J. Electroceramics, vol. 17, no. 2-4, pp. 975-978, Dec. 2006.

[40] O. Lupan, G. Chai, and L. Chow, "Novel hydrogen gas sensor based on single ZnO nanorod," Microelectron. Eng., vol. 85, no. 11, pp. 2220-2225, Nov. 2008.

[41] H.-W. Ra, K.-S. Choi, J.-H. Kim, Y.-B. Hahn, and Y.-H. Im, "Fabrication of ZnO nanowires using nanoscale spacer lithography for gas sensors.," Small, vol. 4, no. 8, pp. 1105-9, Aug. 2008.

[42] S. S. M. Sultan, "Top-Down Fabrication and Characterization of Zinc Oxide Nanowire Field Effect Transistors", PhD thesis, University of Southampton, April 2013.

[43] S. Y. Park, B. J. Kim, K. Kim, M. S. Kang, K. H. Lim, T. Il Lee, J. M. Myoung, H. K. Baik, J. H. Cho, and Y. S. Kim, "Low-temperature, solution-processed and alkali metal doped zno for high-performance thin-film transistors," Adv. Mater., vol. 24, no. 6, pp. 834-838, Feb. 2012.

[44] M. Ortel and V. Wagner, "Leidenfrost temperature related CVD-like growth mechanism in ZnO-TFTs deposited by pulsed spray pyrolysis," J. Cryst. Growth, vol. 363, pp. 185-189, Jan. 2013.

[45] S. M. Sultan, N. J. Ditshego, R. Gunn, P. Ashburn, and H. M. Chong, "Effect of atomic layer deposition temperature on the performance of top-down $\mathrm{ZnO}$ nanowire transistors.," Nanoscale Res. Lett., vol. 9, no. 1, p. 517, Jan. 2014.

[46] Z. Ye and M. Wong, "Characteristics of thin-film transistors fabricated on fluorinated zinc oxide," Electron Device Lett. IEEE, vol. 33, no. 4, pp. 549-551, Apr. 2012.

[47] J. Yang, J. K. Park, S. Kim, W. Choi, S. Lee, and H. Kim, “Atomic-layer-deposited ZnO thinfilm transistors with various gate dielectrics," Phys. Status Solidi Appl. Mater. Sci., vol. 209, no. 10, pp. 2087-2090, Oct. 2012. 
[48] J. Yang, J. K. Park, S. Kim, W. Choi, S. Lee, and H. Kim, "Atomic-layer-deposited ZnO thinfilm transistors with various gate dielectrics," Phys. Status Solidi, vol. 209, no. 10, pp. 20872090, Oct. 2012.

[49] E. Chong, B. Kim, and S. Lee, "Reduction of channel resistance in amorphous oxide thin-film transistors with buried layer," IOP Conf. Ser. Mater., vol. 34, p. 012005 (6 pp.), 2012.

[50] B. Su, S. Chu, and Y. Juang, "Improved Electrical and Thermal Stability of Solution-Processed Li-Doped ZnO Thin-Film Transistors," Electron Devices, IEEE, vol. 59, no. 3, pp. 700-704, Mar. 2012.

[51] K. Choi, S. Jeon, and H. Kim, "A comparison of Ga: $\mathrm{ZnO}$ and Ga: $\mathrm{ZnO} / \mathrm{Ag} / \mathrm{Ga}: \mathrm{ZnO}$ source/drain electrodes for In-Ga-Zn-O thin film transistors," Mater. Res. Bull., vol. 47, no. 10, pp. 2915-2918, Oct. 2012.

[52] R. Chen, W. Zhou, and M. Zhang, "Self-Aligned Indium-Gallium-Zinc Oxide Thin-Film Transistor With Phosphorus-Doped Source/Drain Regions," Device Lett. IEEE, vol. 33, no. 8, pp. 1150-1152, Aug. 2012.

[53] D. Geng and D. Kang, "High-speed and low-voltage-driven shift register with self-aligned coplanar a-IGZO TFTs," Device Lett. IEEE, vol. 33, no. 7, pp. 1012-1014, Jul. 2012.

[54] S. Li, Y. Cai, D. Han, and Y. Wang, "Low-Temperature ZnO TFTs Fabricated by Reactive Sputtering of Metallic Zinc Target," Electron Devices, vol. 59, no. 9, pp. 2555-2558, Sep. 2012.

[55] G. Adamopoulos, S. Thomas, P. H. Woebkenberg, D. D. C. Bradley, M. A. McLachlan, and T. D. Anthopoulos, "High-Mobility Low-Voltage $\mathrm{ZnO}$ and Li-Doped $\mathrm{ZnO}$ Transistors Based on ZrO2 High-k Dielectric Grown by Spray Pyrolysis in Ambient Air," Adv. Mater., vol. 23, no. 16, p. 1894, Apr. 2011.

[56] S. Jeong, J.-Y. Lee, S. S. Lee, S.-W. Oh, H. H. Lee, Y.-H. Seo, B.-H. Ryu, and Y. Choi, "Chemically improved high performance printed indium gallium zinc oxide thin-film transistors," Journal of Materials Chemistry, vol. 21, no. 43. p. 17066, 2011.

[57] R. Navamathavan, R. Nirmala, and C. Lee, "Effect of NH 3 plasma treatment on the device performance of $\mathrm{ZnO}$ based thin film transistors," Vacuum, vol. 85, no. 9, pp. 904-907, Feb. 2011.

[58] E. Kim, K. Lee, D. Kim, G. N. Parsons, K. Park, J. Ihm, and H. Cheong, "SiNx Charge Trap Nonvolatile Memory Based on ZnO Thin Film Transistor Prepared by Atomic Layer Deposition," AIP Conf. Proc., vol. 151, no. 2011, pp. 151-152, 2011.

[59] L. Zhang, J. Li, X. W. Zhang, D. B. Yu, X. Y. Jiang, and Z. L. Zhang, "Glass-substrate-based highperformance ZnO-TFT by using a Ta $2 \mathrm{O} 5$ insulator modified by thin SiO 2 films," Phys. Status Solidi Appl. Mater. Sci., vol. 207, no. 8, pp. 1815-1819, Aug. 2010.

[60] H. Bong, W. H. Lee, D. Y. Lee, B. J. Kim, J. H. Cho, and K. Cho, "High-mobility lowtemperature ZnO transistors with low-voltage operation," Appl. Phys. Lett., vol. 96, no. 19, p. 192115 (3 pp.), May 2010.

[61] A. Lu, J. Sun, J. Jiang, and Q. Wan, "Low-voltage transparent electric-double-layer ZnO-based thin-film transistors for portable transparent electronics," Appl. Phys. Lett., vol. 96, no. 4, p. 043114 (3 pp.), Jan. 2010.

[62] L. Zhang, J. Li, and X. Zhang, "Low-voltage-drive and high output current ZnO thin-film transistors with sputtering $\mathrm{SiO} 2$ as gate insulator," Curr. Appl., vol. 10, no. 5, pp. 1306-1308, Sep. 2010.

[63] D. A. Mourey, S. Member, D. A. Zhao, and T. N. Jackson, "Self-Aligned-Gate ZnO TFT Circuits," vol. 31, no. 4, pp. 326-328, 2010. 
[64] B. Bayraktaroglu, "Microwave ZnO thin-film transistors," Electron Device Lett. ..., vol. 29, no. 9, pp. 1024-1026, Sep. 2008.

[65] J. Zhu, H. Chen, G. Saraf, and Z. Duan, "ZnO TFT devices built on glass substrates," J. Electron., vol. 37, no. 9, pp. 1237-1240, 2008.

[66] A. Wei, L. Pan, and W. Huang, "Recent progress in the $\mathrm{ZnO}$ nanostructure-based sensors," Materials Science and Engineering B: Solid-State Materials for Advanced Technology, vol. 176, no. 18. pp. 1409-1421, 2011.

[67] Y. Xia, P. Yang, Y. Sun, Y. Wu, B. Mayers, B. Gates, Y. Yin, F. Kim, and H. Yan, “OneDimensional Nanostructures: Synthesis, Characterization, and Applications," ChemInform, vol. 34, no. 22, Jun. 2003.

[68] S. Donthu, Z. Pan, B. Myers, G. Shekhawat, N. Wu, and V. Dravid, "Facile scheme for fabricating solid-state nanostructures using e-beam lithography and solution precursors.," Nano Lett., vol. 5, no. 9, pp. 1710-5, Sep. 2005.

[69] L. Ming, Z. Hai-Ying, G. Chang-Xin, X. Jing-Bo, and F. Xiao-Jun, "The research on suspended $\mathrm{ZnO}$ nanowire field-effect transistor," Chinese Phys. B, vol. 18, no. 4, pp. 1594-1597, Apr. 2009.

[70] M. M. A Hakim, M. Lombardini, K. Sun, F. Giustiniano, P. L. Roach, D. E. Davies, P. H. Howarth, M. R. R. de Planque, H. Morgan, and P. Ashburn, "Thin film polycrystalline silicon nanowire biosensors.," Nano Lett., vol. 12, no. 4, pp. 1868-72, Apr. 2012.

[71] H. Ge, W. Wu, Z. Li, G.-Y. Jung, D. Olynick, Y. Chen, J. A. Liddle, S.-Y. Wang, and R. S. Williams, "Cross-linked polymer replica of a nanoimprint mold at $30 \mathrm{~nm}$ half-pitch.," Nano Lett., vol. 5, no. 1, pp. 179-82, Jan. 2005.

[72] T. Weber, T. Käsebier, A. Szeghalmi, M. Knez, E.-B. Kley, and A. Tünnermann, "Iridium wire grid polarizer fabricated using atomic layer deposition," Nanoscale Research Letters, 2011. [Online].

Available: http://www.researchgate.net/profile/Mato_Knez/publication/51738965_Iridium_wire_grid_po larizer_fabricated_using_atomic_layer_deposition/links/0fcfd511134d $1 \overline{1} \mathrm{c} 51 \mathrm{~b} 7000000$.pdf. [Accessed: 26-May-2015].

[73] X. Liu, X. Deng, P. Sciortino, M. Buonanno, F. Walters, R. Varghese, J. Bacon, L. Chen, N. O’Brien, and J. J. Wang, "Large area, $38 \mathrm{~nm}$ half-pitch grating fabrication by using atomic spacer lithography from aluminum wire grids.," Nano Lett., vol. 6, no. 12, pp. 2723-7, Dec. 2006.

[74] C. Hsu and T. Tsai, "Fabrication of fully transparent indium-doped $\mathrm{ZnO}$ nanowire field-effect transistors on ITO/glass substrates," J. Electrochem. Soc., vol. 158, no. 2, pp. K20-K23, Feb. 2011.

[75] S. Peng, Y. Su, and L. Ji, "Semitransparent field-effect transistors based on $\mathrm{ZnO}$ nanowire networks," Device Lett. IEEE, vol. 32, no. 4, pp. 533-535, Apr. 2011.

[76] C. G. Kang, J. W. Kang, S. K. Lee, S. Y. Lee, C. H. Cho, H. J. Hwang, Y. G. Lee, J. Heo, H.J. Chung, H. Yang, S. Seo, S.-J. Park, K. Y. Ko, J. Ahn, and B. H. Lee, "Characteristics of CVD graphene nanoribbon formed by a ZnO nanowire hardmask.," Nanotechnology, vol. 22, no. 29, p. 295201, Jul. 2011.

[77] Y. Wang, X. W. Sun, J. Zhao, G. K. L. Goh, L. Chen, L.-L. Liew, J. Qiu, And Y.-H. Hwang, "Comparison of the hydrothermal and VPT grown zno nanowire field effect transistors," International Journal of Nanoscience, vol. 09, no. 4. pp. 317-320, Aug-2010.

[78] W. I. Park, J. S. Kim, G. C. Yi, and H. J. Lee, "ZnO nanorod logic circuits," Adv. Mater., vol. 17, no. 11, p. 1393, Jun. 2005. 
[79] S. Ju, K. Lee, D. B. Janes, R. C. Dwivedi, H. Baffour-Awuah, R. Wilkins, M.-H. Yoon, A. Facchetti, and T. J. Marks, "Proton radiation hardness of single-nanowire transistors using robust organic gate nanodielectrics," Appl. Phys. Lett., vol. 89, no. 13, pg 073510, Sep. 2006.

[80] Y. Heo, L. Tien, and Y. Kwon, "Depletion-mode $\mathrm{ZnO}$ nanowire field-effect transistor," Appl. Phys, vol. 85, no. 12, pp. 2274-22762276, Sep. 2004.

[81] H. T. Ng, J. Han, T. Yamada, P. Nguyen, Y. P. Chen, and M. Meyyappan, "Single Crystal Nanowire Vertical Surround-Gate Field-Effect Transistor," Nano Lett., vol. 4, no. 7, pp. 12471252, Jul. 2004.

[82] J. Y. Park, Y. S. Yun, Y. S. Hong, H. Oh, J. J. Kim, and S. S. Kim, "Synthesis, electrical and photoresponse properties of vertically well-aligned and epitaxial $\mathrm{ZnO}$ nanorods on $\mathrm{GaN}$ buffered sapphire substrates," Appl. Phys. Lett., vol. 87, no. 12, pp. 1-3, Sep. 2005.

[83] W. Wang, H. D. Xiong, M. D. Edelstein, D. Gundlach, J. S. Suehle, C. A. Richter, W.-K. Hong, and T. Lee, "Low frequency noise characterizations of $\mathrm{ZnO}$ nanowire field effect transistors," J. Appl. Phys., vol. 101, no. 4, Feb. 2007.

[84] H. Kim, J.-H. Park, M. Suh, J. Real Ahn, and S. Ju, "Horizontally aligned ZnO nanowire transistors using patterned graphene thin films," Appl. Phys. Lett., vol. 100, no. 6, p. 063112, 2012.

[85] S. Das, J. H. Kim, H. S. Choi, Y. K. Park, and Y. B. Hahn, "Interfacial and electrical properties of solution processed p-TiO 2 in heterojunction devices," Electrochem. commun., vol. 13, no. 4, pp. 350-354, Apr. 2011.

[86] R. Noriega, J. Rivnay, L. Goris, D. Kälblein, H. Klauk, K. Kern, L. M. Thompson, A. C. Palke, J. F. Stebbins, J. R. Jokisaari, G. Kusinski, and A. Salleo, "Probing the electrical properties of highly-doped Al:ZnO nanowire ensembles," J. Appl. Phys., vol. 107, no. 7, p. 074312 (7 pp.), Apr. 2010.

[87] D. R. Thévenot, K. Toth, R. A. Durst, and G. S. Wilson, "Electrochemical biosensors: Recommended definitions and classification," Biosens. Bioelectron., vol. 16, no. 1-2, pp. 121$131,2001$.

[88] S. Roy and Z. Gao, "Nanostructure-based electrical biosensors," Nano Today, vol. 4, no. 4, pp. 318-334, Aug. 2009.

[89] J. Jung, S. J. Kim, K. W. Lee, D. H. Yoon, Y.-G. Kim, H. Y. Kwak, S. R. Dugasani, S. H. Park, and H. J. Kim, "Approaches to label-free flexible DNA biosensors using low-temperature solution-processed InZnO thin-film transistors.," Biosens. Bioelectron., vol. 55, pp. 99-105, May 2014.

[90] K. Chen, B. Li, and Y. Chen, "Silicon nanowire field-effect transistor-based biosensors for biomedical diagnosis and cellular recording investigation," Nano Today, vol. 6, no. 2, pp. 131154, Apr. 2011.

[91] M. Yano, K. Koike, K. I. Ogata, T. Nogami, S. Tanabe, and S. Sasa, "Zinc oxide-based biosensors," Phys. Status Solidi Curr. Top. Solid State Phys., vol. 9, no. 7, pp. 1570-1573, 2012.

[92] J. Liu, J. Goud, P. M. Raj, M. Iyer, Z. L. Wang, and R. R. Tummala, "Real-time protein detection using $\mathrm{ZnO}$ nanowire/thin film bio-sensor integrated with microfluidic system," in Proceedings - Electronic Components and Technology Conference, pp. 1317-1322, 2008.

[93] X. Liu, P. Lin, X. Yan, Z. Kang, Y. Zhao, Y. Lei, C. Li, H. Du, and Y. Zhang, "Enzyme-coated single $\mathrm{ZnO}$ nanowire FET biosensor for detection of uric acid," Sensors Actuators B Chem., vol. 176, pp. 22-27, Jan. 2013. 
[94] M. A Mohd Azmi, Z. Tehrani, R. P. Lewis, K. D. Walker, D. R. Jones, D. R. Daniels, S. H. Doak, and O. J. Guy, "Highly sensitive covalently functionalised integrated silicon nanowire biosensor devices for detection of cancer risk biomarker.," Biosens. Bioelectron., vol. 52, pp. 216-24, Feb. 2014.

[95] Y.-C. Shen, C.-H. Yang, S.-W. Chen, S.-H. Wu, T.-L. Yang, and J.-J. Huang, "IGZO thin film transistor biosensors functionalized with $\mathrm{ZnO}$ nanorods and antibodies.," Biosens. Bioelectron., vol. 54, pp. 306-10, Apr. 2014.

[96] A. Choi, K. Kim, H.-I. Jung, and S. Y. Lee, "ZnO nanowire biosensors for detection of biomolecular interactions in enhancement mode," Sensors Actuators B Chem., vol. 148, no. 2, pp. 577-582, Jul. 2010.

[97] Y. Cui, Q. Wei, H. Park, and C. Lieber, "Nanowire nanosensors for highly sensitive and selective detection of biological and chemical species," Science (80-. )., vol. 293, no. 5533, pp. 1289-1292, Aug. 2001.

[98] G. Zheng, F. Patolsky, Y. Cui, W. U. Wang, and C. M. Lieber, "Multiplexed electrical detection of cancer markers with nanowire sensor arrays.," Nat. Biotechnol., vol. 23, no. 10, pp. 1294301, Oct. 2005.

[99] W. Lu, P. Xie, and C. M. Lieber, "Nanowire Transistor Performance Limits and Applications," IEEE Trans. Electron Devices, vol. 55, no. 11, pp. 2859-2876, Nov. 2008.

[100] Z. Li, Y. Chen, X. Li, T. I. Kamins, K. Nauka, and R. S. Williams, "Sequence-Specific LabelFree DNA Sensors Based on Silicon Nanowires," Nano Lett., vol. 4, no. 2, pp. 245-247, Feb. 2004.

[101] Y. L. Bunimovich, Y. S. Shin, W.-S. Yeo, M. Amori, G. Kwong, and J. R. Heath, "Quantitative real-time measurements of DNA hybridization with alkylated nonoxidized silicon nanowires in electrolyte solution.," J. Am. Chem. Soc., vol. 128, no. 50, pp. 16323-31, Dec. 2006.

[102] B. R. Dorvel, B. Reddy, J. Go, C. Duarte Guevara, E. Salm, M. A. Alam, and R. Bashir, "Silicon nanowires with high-k hafnium oxide dielectrics for sensitive detection of small nucleic acid oligomers.," ACS Nano, vol. 6, no. 7, pp. 6150-64, Jul. 2012.

[103] I. Park, Z. Li, X. Li, A. P. Pisano, and R. S. Williams, "Towards the silicon nanowire-based sensor for intracellular biochemical detection.," Biosens. Bioelectron., vol. 22, no. 9-10, pp. 2065-70, Apr. 2007.

[104] A. Tarasov, M. Wipf, K. Bedner, and J. Kurz, "True reference nanosensor realized with silicon nanowires," Langmuir, 2012.

[105] G.-J. Zhang, L. Zhang, M. J. Huang, Z. H. H. Luo, G. K. I. Tay, E.-J. A. Lim, T. G. Kang, and Y. Chen, "Silicon nanowire biosensor for highly sensitive and rapid detection of Dengue virus," Sensors Actuators B Chem., vol. 146, no. 1, pp. 138-144, Apr. 2010.

[106] E. Stern, J. Klemic, and D. Routenberg, "Label-free immunodetection with CMOS-compatible semiconducting nanowires," Nature, vol. 445, no. 7127, pp. 519-522, Feb. 2007.

[107] M.-H. Lee, K.-N. Lee, S.-W. Jung, W.-H. Kim, K.-S. Shin, and W.-K. Seong, "Quantitative measurements of C-reactive protein using silicon nanowire arrays.," Int. J. Nanomedicine, vol. 3, no. 1, pp. 117-24, Jan. 2008.

[108] S. Chen, J. G. Bomer, W. G. van der Wiel, E. T. Carlen, and A. van den Berg, "Top-down fabrication of sub-30 nm monocrystalline silicon nanowires using conventional microfabrication.," ACS Nano, vol. 3, no. 11, pp. 3485-92, Nov. 2009. 
[109] K. Sun, I. Zeimpekis, M. Lombardini, N. M. J. Ditshego, S. J. Pearce, K. S. Kiang, O. Thomas, M. R. R. De Planque, H. M. H. Chong, H. Morgan, and P. Ashburn, "Three-mask polysilicon thin-film transistor biosensor," IEEE Trans. Electron Devices, vol. 61, no. 6, pp. 2170-2176, 2014.

[110] M. Curreli, R. Zhang, F. N. Ishikawa, H. K. Chang, R. J. Cote, C. Zhou, and M. E. Thompson, "Real-time, label-free detection of biological entities using nanowire-based FETs," IEEE Trans. Nanotechnol., vol. 7, no. 6, pp. 651-667, Nov. 2008.

[111] Y. Zhang, Z. Kang, X. Yan, and Q. Liao, “ZnO nanostructures in enzyme biosensors," Sci. China Mater., vol. 58, no. 1, pp. 60-76, Jan. 2015.

[112] Y. Lei, X. Yan, N. Luo, Y. Song, and Y. Zhang, "ZnO nanotetrapod network as the adsorption layer for the improvement of glucose detection via multiterminal electron-exchange," Colloids Surfaces A Physicochem. Eng. Asp., vol. 361, no. 1-3, pp. 169-173, May 2010.

[113] J. X. Wang, X. W. Sun, A. Wei, Y. Lei, X. P. Cai, C. M. Li, and Z. L. Dong, "Zinc oxide nanocomb biosensor for glucose detection," Appl. Phys. Lett., vol. 88, no. 23, p. 233106, Jun. 2006.

[114] F. Zhang, X. Wang, S. Ai, Z. Sun, Q. Wan, Z. Zhu, Y. Xian, L. Jin, and K. Yamamoto, "Immobilization of uricase on $\mathrm{ZnO}$ nanorods for a reagentless uric acid biosensor," Anal. Chim. Acta, vol. 519, no. 2, pp. 155-160, Aug. 2004.

[115] S. M. U. Ali, Z. H. Ibupoto, M. Kashif, U. Hashim, and M. Willander, "A potentiometric indirect uric acid sensor based on $\mathrm{ZnO}$ nanoflakes and immobilized uricase.," Sensors (Basel)., vol. 12, no. 3, pp. 2787-97, Jan. 2012.

[116] K. Jindal, M. Tomar, and V. Gupta, "Inducing electrocatalytic functionality in ZnO thin film by $\mathrm{N}$ doping to realize a third generation uric acid biosensor.," Biosens. Bioelectron., vol. 55, pp. 57-65, May 2014.

[117] A. K. Giri, A. Sinhamahapatra, S. Prakash, J. Chaudhari, V. K. Shahi, and A. B. Panda, "Porous $\mathrm{ZnO}$ microtubes with excellent cholesterol sensing and catalytic properties," J. Mater. Chem. $A$, vol. 1, no. 3, pp. 814-822, Dec. 2013.

[118] R. Ahmad, N. Tripathy, and Y.-B. Hahn, "Wide linear-range detecting high sensitivity cholesterol biosensors based on aspect-ratio controlled $\mathrm{ZnO}$ nanorods grown on silver electrodes," Sensors Actuators B Chem., vol. 169, pp. 382-386, Jul. 2012.

[119] A. Wei, X. W. Sun, J. X. Wang, Y. Lei, X. P. Cai, C. M. Li, Z. L. Dong, and W. Huang, "Enzymatic glucose biosensor based on $\mathrm{ZnO}$ nanorod array grown by hydrothermal decomposition," Appl. Phys. Lett., vol. 89, no. 12, p. 123902, Sep. 2006.

[120] K. Yang, G.-W. She, H. Wang, X.-M. Ou, X.-H. Zhang, C.-S. Lee, and S.-T. Lee, "ZnO Nanotube Arrays as Biosensors for Glucose," J. Phys. Chem. C, vol. 113, no. 47, pp. 2016920172, Nov. 2009.

[121] G. Aydoğdu, D. K. Zeybek, Ş. Pekyardımcı, and E. Kılıç, “A novel amperometric biosensor based on $\mathrm{ZnO}$ nanoparticles-modified carbon paste electrode for determination of glucose in human serum.," Artif. cells, nanomedicine, Biotechnol., vol. 41, no. 5, pp. 332-8, Oct. 2013.

[122] M. Ahmad, C. Pan, Z. Luo, and J. Zhu, "A single ZnO nanofiber-based highly sensitive amperometric glucose biosensor," J. Phys. Chem. C, vol. 114, no. 20, pp. 9308-9313, May 2010.

[123] A. Fulati, S. M. U. Ali, M. H. Asif, N. ul H. Alvi, M. Willander, C. Brännmark, P. Strålfors, S. I. Börjesson, F. Elinder, and B. Danielsson, "An intracellular glucose biosensor based on nanoflake ZnO,” Sensors Actuators B Chem., vol. 150, no. 2, pp. 673-680, Oct. 2010. 
[124] Z. Yang, X. Zong, Z. Ye, B. Zhao, Q. Wang, and P. Wang, "The application of complex multiple forklike $\mathrm{ZnO}$ nanostructures to rapid and ultrahigh sensitive hydrogen peroxide biosensors.," Biomaterials, vol. 31, no. 29, pp. 7534-41, Oct. 2010.

[125] J. Liu, C. Guo, C. M. Li, Y. Li, Q. Chi, X. Huang, L. Liao, and T. Yu, "Carbon-decorated ZnO nanowire array: A novel platform for direct electrochemistry of enzymes and biosensing applications," Electrochem. commun., vol. 11, no. 1, pp. 202-205, Jan. 2009.

[126] C. Yang, C. Xu, and X. Wang, "ZnO/Cu nanocomposite: a platform for direct electrochemistry of enzymes and biosensing applications.," Langmuir, vol. 28, no. 9, pp. 4580-5, Mar. 2012.

[127] Z. W. Zhao, X. J. Chen, B. K. Tay, J. S. Chen, Z. J. Han, and K. A. Khor, "A novel amperometric biosensor based on $\mathrm{ZnO}$ :Co nanoclusters for biosensing glucose," Biosens. Bioelectron., vol. 23, no. 1, pp. 135-139, Aug. 2007.

[128] Y. Wei, Y. Li, X. Liu, Y. Xian, G. Shi, and L. Jin, "ZnO nanorods/Au hybrid nanocomposites for glucose biosensor.," Biosens. Bioelectron., vol. 26, no. 1, pp. 275-8, Sep. 2010.

[129] X. Chu, X. Zhu, Y. Dong, T. Chen, M. Ye, and W. Sun, “An amperometric glucose biosensor based on the immobilization of glucose oxidase on the platinum electrode modified with $\mathrm{NiO}$ doped ZnO nanorods," J. Electroanal. Chem., vol. 676, pp. 20-26, Jul. 2012.

[130] S. K. Shukla, S. R. Deshpande, S. K. Shukla, and A. Tiwari, "Fabrication of a tunable glucose biosensor based on zinc oxide/chitosan-graft-poly(vinyl alcohol) core-shell nanocomposite.," Talanta, vol. 99, pp. 283-7, Sep. 2012.

[131] C. Karuppiah, S. Palanisamy, S.-M. Chen, V. Veeramani, and P. Periakaruppan, "Direct electrochemistry of glucose oxidase and sensing glucose using a screen-printed carbon electrode modified with graphite nanosheets and zinc oxide nanoparticles," Microchim. Acta, vol. 181, no. 15-16, pp. 1843-1850, Apr. 2014.

[132] Y.-T. Wang, L. Yu, Z.-Q. Zhu, J. Zhang, J.-Z. Zhu, and C. Fan, "Improved enzyme immobilization for enhanced bioelectrocatalytic activity of glucose sensor," Sensors Actuators B Chem., vol. 136, no. 2, pp. 332-337, Mar. 2009.

[133] S. Palanisamy, S. Cheemalapati, and S. M. Chen, "Enzymatic glucose biosensor based on multiwalled carbon nanotubes-zinc oxide composite," Int. J. Electrochem. Sci., vol. 7, no. 9, pp. 8394-8407, 2012.

[134] N.M.J. Ditshego and S.M. Sultan, "Top-Down Fabrication Process of ZnO NWFETs", Journal of Nano Research, Vol. 57, pp 77-92, Feb. 2019

[135] W. U. Wang, C. Chen, K. H. Lin, Y. Fang, and C. M. Lieber, "Labelfree detection of smallmolecule-protein interactions by using nanowire nanosensors," in Proc. Nat. Acad. Sci. USA, 2005, vol. 102, pp. 3208-3212, 2005. 